Ann. Génét. Sél. anim., 1982, 14 (3), 421-426

Note

\title{
Effect of one cycle of divergent selection for shell length in Helix aspersa Müll
}

\author{
F. PANELLA \\ Istituto di Zootecnica Generale, Facoltà di Agraria \\ Università degli Studi di Perugia \\ Borgo XX Giugno 74, 06100 Perugia, Italia
}

\begin{abstract}
Summary
One cycie of divergent selection has been carried out in Helix aspersa Müll in order to study the heritability of body size and the possibility of improving this character by suitable programs of selection.

The realized heritability was 0.19 for the increase in length and 0.13 for the decrease in length; the $\mathrm{h}^{2}$ estimate by regression was 0.16 . Furthermore the differences between the control group and the selected groups show that it is possible to select for the size improvement.
\end{abstract}

\section{Introduction}

The Gasteropoda Pulmonates have been mainiy studied for protein polymorphism (HAKAN et al., 1973 ; MANWEll et al., 1968) and for genetic structure (BANTOK, 1972 ; Evans, 1960). On the contrary, since the interest aroused by snail breeding is very recent, the snail's economic performance (WOLDA, 1970) by suitable programs of genetic selection is practically unknown.

Previous experiments (Panella, $1979 \mathrm{a}, \mathrm{b}$ ) carried out in order to study the rearing of Helix aspersa Müll. in artificial environment, have shown a considerable variation in size among individuals of the same brood, and therefore the possibility of improving average dimensions.

\section{Materials and methods}

The character studied was shell length measured in $\mathrm{mm}$ as indicated in fig. 1. The Helix aspersa shell develops from the egg's surface membrane ; so the dimension of new borns depends on the egg size. When the snail grows the shell is progressively and continously enlarged; therefore it represents a suitable index of animal growth. 
The selection method employed was divergent selection with a control population. This method was chosen because it permits a test of the possibility of improving genetically shell size and, at the same time, a test of the disadvantage caused by the maintenance of small snails as parents.

Four hundred snails, chosen at random, of the same age but coming from different fields of the samc geographical area (near Perugia), representing the base population, were reared in artificial environment conditions at $20^{\circ} \mathrm{C}, 80$ p. 100 relative humidity, luminous intensity of 500 lux with a photoperiod of 12 hours of light and 12 hours of darkness.

When the snails reached seven months of age was measured their shell length. A group of 12 snails was chosen at random out of the whole population as the control group; then the 12 largest and 12 smallest individuals formed the groups selected for long and for short dimension respectively.

The selected material was tested against the control group rather then against the base population as a whole in order to avoid environmental effects such as different diet or different season of growth between selected groups and base population.

For every group the snails were placed as pairs in suitable boxes where they mated and layed eggs. For every parental pair five broods were reared separately in special cages as previousely described for the base population. The whole population of snails obtained was 1590 individuals : 535 in the control, 608 in the long and 477 in the short group.

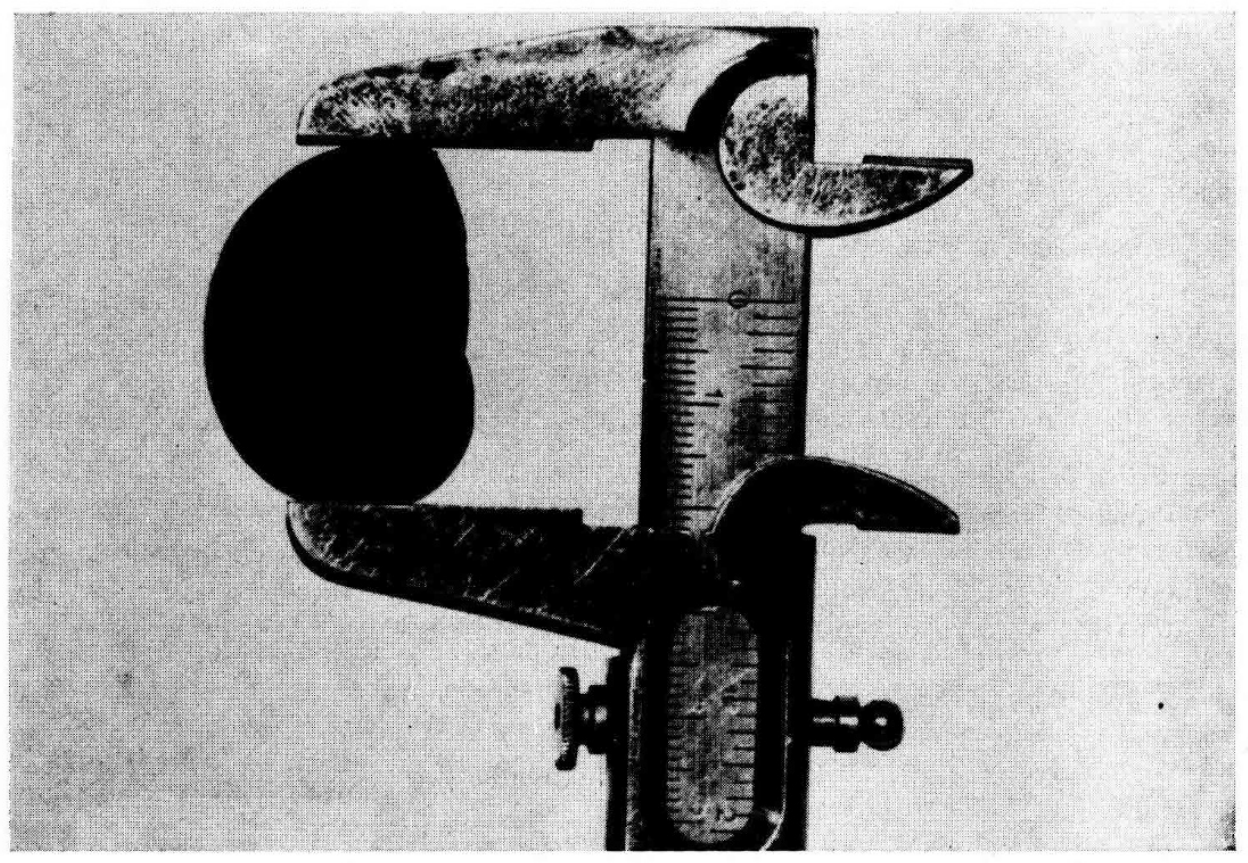

FIG. 1

Measure of shell length.

Mesure de la longueur de la coquille. 


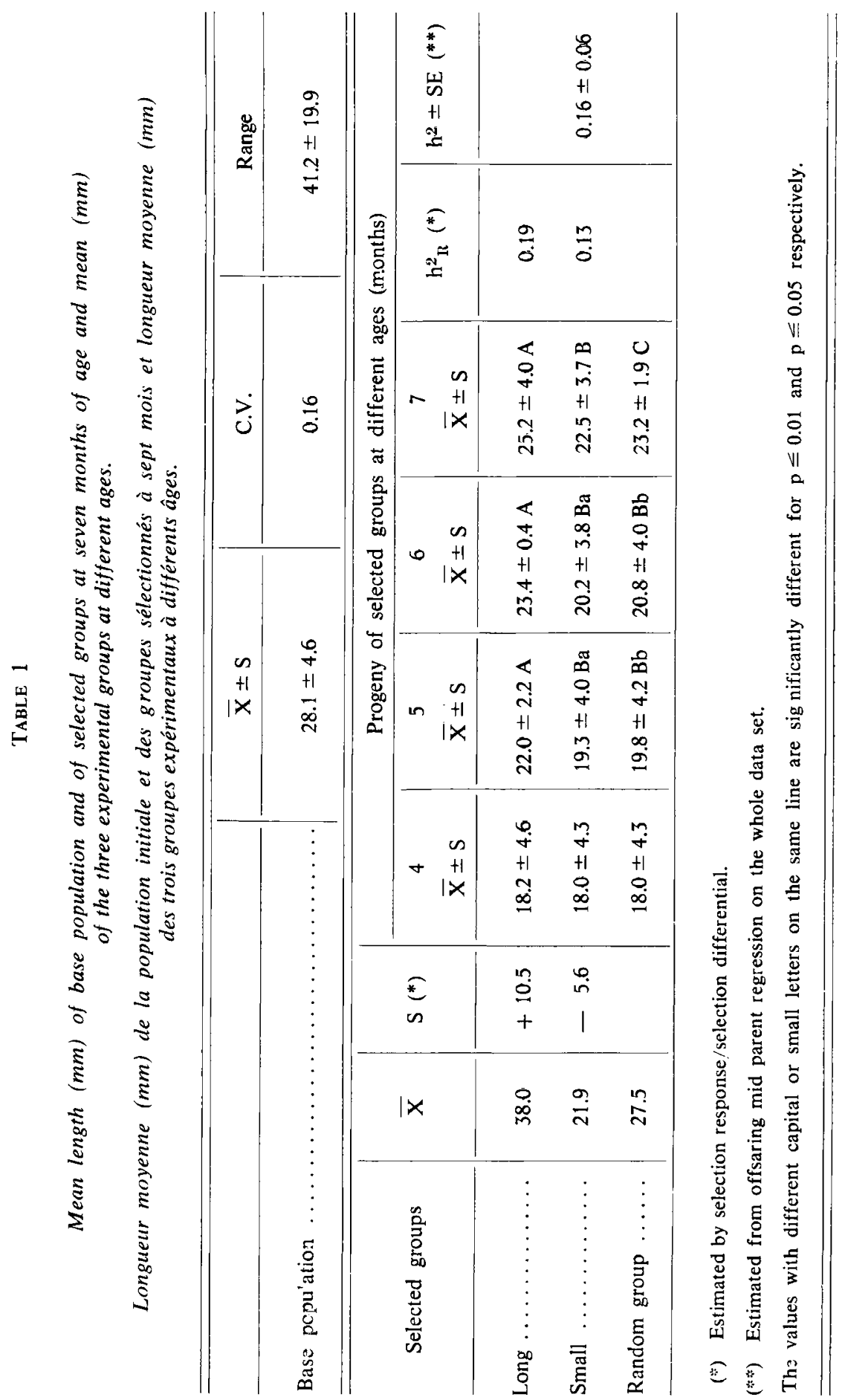


The shell length of each animal was measured every month, for 7 months; after this age it was assumed that the fast increase period was finished and the commercial size reached.

From the fifth month of age snail's length was influenced by brood density $(r=-0.26)$; therefore, to avoid the error due to the different number of individuals per brood the data were corrected by analysis of covariance.

The differences between the three experimental groups and between the several brood in every group were evaluated by the usual statistical methods (SALvi et al., 1978 ; SNEDECOR \& Cochran, 1967).

The estimation of heritability $\left(h^{2}\right)$ was measured by the regression of offspring on mid-parent (FAlCONER, 1960).

\section{II. Results and discussion}

The basc popuation was characterized by a strong variation as shown in Table 1 (Coefficient of Variation $=0.16)$; the high variation of this group is due to the presence of animals of all dimensions (Range $=41.2-19.9$ ). This difference is not exceptional because the same was observed in other experiments (Panella, 1979 a, b).

The selection differentials $(S)$ for the two selected groups were $+10.5 \mathrm{~mm}$ and - $5.6 \mathrm{~mm}$ as deviation from the randomly chosen control group. The selection was very efficient as shown by highly significant differences between the mean lengths of the three experimental groups measured at 7 months of age. The size of the progeny in the upward selected group was increased by 9 p. 100 and that of the downward selected group was reduced by about 3 p. 100 in comparison with the control group. The difference between the three groups started to be evident at an age of 5 months, and mostly in the subjects selected for the large size.

TABLE 2

Mature snails (p. 100) and their length $(\bar{X} \pm S)$ at seven months age.

Escargots adultes (p. 100) et leur longueur $(\vec{X} \pm S)$ à l'âge de sept mois.

\begin{tabular}{|c|c|c|c|}
\hline Groups & $\%$ & $\begin{array}{l}\text { Length } \\
\bar{X} \pm S\end{array}$ & F \\
\hline 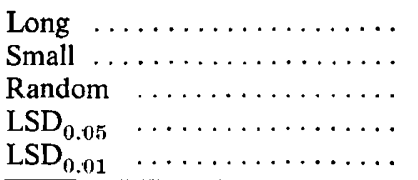 & $\begin{array}{r}7.5 \\
14.0 \\
6.8\end{array}$ & $\begin{array}{c}33.9 \pm 2.7 \\
28.4 \pm 2.0 \\
33.2 \pm 4.0 \\
1.2 \\
1.6\end{array}$ & $6.04\left(^{* *}\right)$ \\
\hline
\end{tabular}

$(* *) \quad P \leq 0.01$. 
The realized heritability (selection gain/selection differential) was 0.19 for length increase and 0.13 for length decrease, the heritability, estimated by regression of offspring length on mid-parent length, was 0.16 .

The standard deviations of the broods in the groups shows that the phenotypic variation was not reduced by one cycle of selection and that it is possible to obtain better performance gain by advanced selection.

In order to ascertain if the superiority and inferiority of the snails selected in upward and downward direction respectively, was caused by a different speed of growth or by a change in somatic development, the percentage of mature snails (peristome edge jutting out) in the three experimental groups was calculated and the difference in length for these mature individuals was evaluated by analysis of variance. Data in Table 2 show that in the selected groups the individual somatic development was independent of adult size ; the smallest group, in fact, had the highest percentage of developed individuals (14 p. 100).

The results of this research have shown that shell length in Helix aspersa Müll is character of intermediate heritability and that it is possible to select for the size improvement; only one cycle of selection obtained a positive response in both directions; the high variation present in the two selected groups indicates also that a further improvement of this character is possible.

Received for publication in january 1982.

\section{Résumé \\ Bilan d'un cycle de sélection divergente sur la taille de la coquille chez Helix Aspersa Müll.}

On a effectué, chez Helix Aspersa Müll, un cycle de sélection divergente sur la longueur de la coquille en vue d'apprécier l'héritabilité de ce caractère et la possibilité de le sélectionner.

L'héritabilité réalisée a été estimée à 0,19 et 0,13 dans les lignées haute et basse respectivement, tandis que l'estimation obtenue à partir de la régression du descendant sur le parent moyen était de 0,16 . Le cycle de sélection divergente effectué a conduit à une modification sensible dans les deux directions de la taille de la coquille par rapport au groupe témoin.

\section{References}

Bantock C.R., 1972. Localisation of chiasmata in Cepaea nemoralis L. Heredity, 29, 213-221.

Evans H.J., 1960. Supernumerary chromosomes in wild population of the snails Helix pomatia L. Heredity, 15, 129-138.

FALCONER D.S., 1960. Introduction to quantitative genetics. Oliver and Boyd Ltd, Edinburgh and London. 
Hakan W., Hakan T., 1973. Polymorphism of esterases and tetrazolium oxidases in the roman snail, Helix pomatia : a study of popolations from Sweden and Germany. Bioch. Genetics, 9, 169-174.

Manwell C., BaKer C.M.A., 1968. Genetic variation of isocitrate, malate and G-phosphogluconate dehydrogenases in snails of the genus Cepaea. Introgressive hybridization, polymorphism and pollution. Comp. Biochern. Physiol., 26, 195.

Panella F., 1979 a. Allevamento in ambiente controllato di Helix aspersa Müll. : primi risultati. Quaderni di Elicicoltura, Borgo S.D., 8, 75-80.

Panella F., 1979 b. Prova di allevamento di Eobania vermiculata Müll. in ambierte controllato. Ann. Fac. Agraria Perugia, XXXIII, 43-55.

Salvi F., Chiandotto B., 1978. Biometria : principi e metodi. Piccin Ed. Padova.

SNedecor G.W., Cochran W.G., 1967. Statistical methods. The Iowa State University Press, Ames, Iowa, U.S.A.

Wolda H., 1970. Variation in yrowth rate 11 the iand snail Cepaea nemorulis L. Res. Pop. Ecol., 12. 185-20.4. 